\title{
Pengembangan Pembelajaran Penulisan Kreatif Berwawasan Lingkungangan Bidang Bahasa dan Sastra Indonesia bagi Guru dan Siswa Pondok Pesantren Muqimus Sunnah di Palembang
}

\author{
Cahyaningrum Dewojati \\ Fakultas Ilmu Budaya, Universitas Gadjah Mada \\ Email: cahyaningrum@ugm.ac.id
}

Tim pengabdian kepada masyarakat:

Cahyaningrum Dewojati, Wira Kurniawati, Septiana Dwiputri Maharani

\begin{abstract}
Abstrak
Salah satu usaha dalam mendukung Sustainable Development Goals (SDGs) 2030 adalah pendidikan akhlak mulia dan pelestarian lingkungan melalui pembelajaran. Dalam hal ini, penulisan kreatif dipandang sebagai sebuah media pembelajaran yang cukup efektif untuk menyampaikan nilai-nilai tersebut. Oleh karenanya, pengembangan pembelajaran penulisan kreatif berwawasan lingkungan bidang bahasa dan sastra Indonesia dipandang perlu sehingga kegiatan pengabdian ini kemudian dilaksanakan di Pondok Pesantren Muqimus Sunnah di Palembang. Tujuan pengabdian ini adalah untuk meningkatkan kreativitas masyarakat dalam bidang penulisan kreatif yang berwawasan lingkungan sebagai usaha mendukung Sustainable Development Goals (SDGs). Metode yang digunakan dalam pengabdian ini adalah pemberian materi dan pelatihan penulisan kreatif berwawasan lingkungan baik dalam bentuk fiksi maupun nonfiksi. Pemberian materi juga disampaikan lewat permainan. Dari pelatihan ini rupanya siswa madrasah dan guru sangat antusias dan lebih bersemangat lagi untuk menulis. Kesimpulannya, pelatihan menulis kreatif yang diujudkan dalam games sastra dan lingkungan, serta kritik terhadap kondisi lingkungan, sangat diperlukan untuk mengasah kekritisan dan kreativitas para santri maupun guru dalam dunia literasi.
\end{abstract}

Kata kunci: Penulisan kreatif, pelatihan, pelestarian lingkungan, sustainable development goals (SDGs)

\footnotetext{
Abstract

One of the efforts in supporting Sustainable Development Goals (SDGs) 2030 is noble moral education and environmental preservation through learning. In this case, creative writing is seen as an effective learning medium to convey these values. Therefore, the development of environmentally sound creative writing study in the field of language and Indonesian literature is considered necessary so that this community engagement activity is then implemented in Pondok Pesantren Muqimus Sunnah in Palembang. The purpose of this community engagement is to improve the creativity of the community in the field of creative writing that is environmentally sound as an effort to support the Sustainable Development Goals (SDGs). The method used in this community engagement is by delivering lectures on creative writing and training in both fiction and nonfiction. Games are also
} 
used as ways to covey the workshop materials. From this training, it seems that madrasah teacher and students are very enthusiastic and more eager to write. In conclusion, creative writing training that is embodied in games, as well as criticism of environmental conditions, is necessary to hone the criticality and creativity of the students and teachers in the world of literacy.

Keywords: Creative writing, training, environmental conservation, sustainable development goals (SDGs).

\section{Pengantar}

Dewasa ini perkembangan aktivitas tulis-menulis mengalami trend dan lonjakan yang cukup signifikan. Selain hadir dalam bentuk hardcopy (buku, majalah, surat kabar, buletin, dan lain-lain), dunia kepenulisan juga berkembang pesat dengan adanya teknologi informasi yang semakin canggih. Aktivitas kreatif menulis menjadi sebuah kebutuhan primer dalam mendukung eksistensi pribadi dan kelompok di era digital. Aktivitas tersebut harus ditopang dengan tuntutan etika dan moral. Sebab, pelatihan penulisan kreatif dengan wawasan ilmu dan semangat penanaman nilai-nilai akhlak yang mulia melalui pengembangan pendidikan dan pembelajaran merupakan salah satu usaha dalam mendukung Sustainable Development Goals (SDGs) 2030 yang selama ini dicanangkan oleh pemerintah.

Salah satu fokus Sustainable Development Goals (SDGs) yang dicanangkan oleh pemerintah dan didukung oleh Universitas Gadjah Mada adalah Education for Sustainable Development (ESD) dalam bidang sosial dan humaniora yang di antaranya adalah pendidikan akhlak mulia dan pelestarian lingkungan. Kesadaran akan kelestarian lingkungan hidup menjadi hal yang mendesak diperlukan ketika pemanasan global semakin tak terkendalikan akibat rusaknya keseimbangan alam. Apabila dikaitkan dengan posisi Indonesia sebagai paru-paru dunia, salah satu hal yang perlu digalakkan adalah kesadaran akan pentingnya pelestarian lingkungan. Oleh karena itu, dalam usaha menyesuaikan dinamika perkembangan zaman, baik produk hardcopy maupun digital, kesadaran akan pelestarian lingkungan salah satunya bisa diwujudkan melalui sebuah tulisan kreatif. Selain itu, wacana tentang alam dan lingkungan sudah cukup populer sebagai inspirasi sebuah tulisan, baik dalam genre fiksi maupun nonfiksi.

Isu lingkungan hidup menarik untuk dikaji karena keberlangsungannya pada masa kini mengalami banyak perubahan. Salah satu cara untuk menciptakan lingkungan yang lestari dan bisa selalu terjaga adalah melalui pendidikan. Sastra sebagai salah satu ilmu sosial berperan penting untuk mendukung kelestarian lingkungan hidup. Sastra mampu merekam kekayaan alam melalui hikayat, syair, gurindam, pepatah, hingga karya sastra modern seperti puisi, cerpen, dan novel. Para pengarang memanfaatkan inspirasi alam tidak hanya sebagai bagian dari romantisme estestis dalam memberikan warna yang berbeda dalam karya sastra, tetapi juga sebagai alat penyadaran sosial dan wacana perjuangan lingkungan hidup. Karya-karya yang sangat kuat mendukung ide-ide penyelamatan lingkungan kritis itu, sangat dekat jika dikaitkan dengan studi ecocritism atau ekokritisme.

Isu tentang gerakan berwawasan lingkungan hidup yang termuat dalam karya sastra ini sejalan dengan teori ekokritisme yang berkembang mulai tahun 1980-an di Barat. Secara sederhana, ecocriticism adalah studi tentang hubungan antara sastra 
dan lingkungan fisik. Seperti halnya kritik feminis yang meneliti bahasa dan sastra dari sebuah kesadaran perspektif gender; dan kritik Marxis yang membawa kesadaran peneliti akan sistem produksi dan kelas ekonomi dalam membaca sebuah teks, maka pendekatan ecocriticism meletakkan bumi sebagai sumber pengabdian sastra (Glotfelty, 1996, hlm. xviii).

Pada prinsipnya, ecocriticism adalah sebuah studi yang membahas cara-cara pengarang dan masyarakat dalam mengimajinasikan dan menggambarkan hubungan antara manusia dengan lingkungan di semua wilayah produksi budaya. Selain itu, ecocriticism adalah studi sastra dan lingkungan dari sudut pandang interdisipliner. Semua bidang ilmu pengetahuan bisa berkontribusi untuk menganalisis lingkungan dan memberi masukan solusi terbaik yang mungkin dilakukan untuk mengoreksi situasi lingkungan kontemporer.

Studi ini telah diawali sekitar tahun 1978 oleh William Rueckert dalam artikelnya yang berjudul Literature and Ecology: An Experiment in Ecocriticism. Setelah itu, studi ini menjadi sangat populer di Barat melalui publikasi dua karya ilmiah yang diterbitkan pada pertengahan 1990-an, yakni The Reader Ecocriticism, disunting oleh Cheryll Glotfelty dan Harold Fromm, dan The Environmental Imagination, oleh Lawrence Buell. (bdk Buell, 1995).

Di Amerika Serikat, istilah ecocriticism ini sering dikaitkan dengan Asosiasi untuk Studi Sastra dan Lingkungan (ASLE), yang menjadi tuan rumah pertemuan dua tahunan bagi para sarjana yang menaruh perhatian terhadap masalah lingkungan yang terkandung dalam sastra. Kelompok ini bahkan menerbitkan jurnal dan memberikan kontribusi penting bagi perkembangan sastra dan lingkungan.

Ecocriticism, seperti yang sekarang ada di Amerika Serikat, adalah keputusan lepas dari kehidupan modern dan berusaha untuk memperbaharui diri dengan 'kembali ke alam'. Sedangkan versi Inggris ecocriticism adalah studi hijau. Istilah itu berusaha memperingatkan kita dari ancaman lingkungan yang berasal dari pemerintah, industri, komersial, dan neokolonial. Sebagai contoh, Bate (2000, hlm. 87) dalam The Song of the Eart, berpendapat bahwa kolonialisme dan deforestasi telah memerosotkan nilai peradaban, imperialisme selalu membawa deforestasi dan mengkonsumsi sumber daya alam.

Ecocritics atau ekokritik meneliti segala sesuatu yang berkaitan dengan nilai-nilai ekologis yang mendasar. Adapun yang dimaksud dengan "tempat" atau lingkungan juga bisa merujuk pada kategori khas, seperti lingkungan kelas, gender, atau ras. Ekokritik juga meneliti persepsi masyarakat terhadap hutan belantara, perubahan alam, dan lingkungan. Studi ini meneliti ada atau tidaknya isu lingkungan saat ini yang secara akurat disuarakan dalam budaya populer dan sastra modern. Disiplin lain, seperti sejarah, filsafat, etika, dan psikologi, juga dianggap oleh ekokritik menjadi kontributor penting untuk pengembangan ecocriticism (Glotfelty, 1996, hlm. xix).

Embrio pemikiran kritis sebenarnya secara sporadis dilakukan oleh para ahli sastra dan budaya sejak tahun 1960-an dan 1970-an tetapi belum dilakukan secara terorganisir. Dengan demikian, ekokritik kadang-kadang menempel pada pengabdian lain seperti studi Amerika dan lain-lain. Sebagai contoh, karya kritikus Marxis Inggris, Raymond Williams, misalnya, menulis kritik sastra pastoral 1973, The Country and the City, yang memberikan gambaran tentang hilangnya tenaga kerja di lingkungan desa karena 
perubahan-perubahan sistem politik, ideologi, dan ekonomi yang sangat cepat.

Adapun teks yang bersifat ekokritik awal lainnya ditulis oleh Joseph Meeker, yakni The Comedy of Survival: Studies in Literary Ecology (1974). Dalam tulisan ini telah muncul isu ecocriticism dan filsafat lingkungan; bahwa krisis lingkungan terutama disebabkan oleh tradisi budaya di Barat yang memisahkan budaya dari alam.

Pada pertengahan 1980-an, para ahli mulai bekerja secara kolektif untuk membangun ecocritism sebagai genre kritik sastra, terutama melalui Asosiasi Sastra Barat. Pada tahun 1990, di University of Nevada di Reno, Glotfelty menjadi orang pertama yang memegang posisi akademis sebagai profesor Sastra dan Lingkungan Hidup. Organisasi ASLE yang didirikan telah menjadi sebuah organisasi dengan ribuan anggota di Amerika Serikat dan berkembang organisasi serupa di Inggris, Jepang, Korea, Australia dan Selandia Baru (ASLEC-ANZ), India (OSLE-India), Taiwan, Kanada, dan Eropa (Barry, 2009).

Estok (2005) menjelaskan bahwa ecocriticism lebih dari studi tentang alam atau halhal yang berkaitan tentang alam dalam sastra. Teori ini berkomitmen untuk melakukan perubahan pandangan masyarakat terhadap alam dengan menganalisis fungsi-tematik, artistik, sosial, sejarah, ideologi, teori, lingkungan alam, beserta segala aspeknya yang terungkap dalam dokumen sastra. Selain itu, pendekatan fungsional ecocriticism pada cabang ekologi budaya, memungkinkan analogi antara ekosistem dan teks imajinatif dalam teks-teks sastra dan budaya memiliki fungsi ekologi (regeneratif dan revitalisasi) dalam sistem budaya. Dalam hal ini karya-karya bisa mencakup budaya pop, film, acara televisi, musik, dan lain-lain.

Secara rinci Estok berpendapat bahwa dalam ekokritik peneliti mampu menjelaskan apa yang dikritik atau disindir dalam sebuah karya sastra tersebut, artinya harus ada kritik terhadap terhadap degradasi lingkungan. Di samping itu, menurut Glotfelty, ekokritik juga bertujuan melacak gagasan lingkungan dan representasinya dalam teks. Dengan demikian diharapkan bisa dengan jelas melihat perdebatan mengenai lingkungan yang muncul di semua bagian teks. Hal ini karena sering tersembunyi di sebuah ruang besar budaya. Pada umumnya, ecocriticism berusaha untuk mengevaluasi teks dan ideide yang mereka gunakan secara koheren sebagai tanggapan terhadap krisis lingkungan (Garrard, 2004, hlm. 4).

Studi ecocritism dimulai dengan membaca kembali karya-karya sastra dari perspektif ecocentric, dengan perhatian khusus pada representasi alam. Kemudian mereka menerapkan berbagai konsep ecocentric, seperti pertumbuhan dan energi, keseimbangan dan ketidakseimbangan, simbiosis dan kebersamaan, dan cara memanfaatkan energi dan sumber daya alam dengan bijaksana.

Menurut Budiyanto (2016, hlm. 11), permasalahan ekologis ini jika dibiarkan akan menjadi ancaman yang membahayakan kehidupan. Oleh karenanya diperlukan kesadaran membangun sinergitas antarsemua pihak untuk menjaga alam dari segala perilaku eksploitatif eksesif. Tanggung jawab ini semestinya tidak hanya menjadi perhatian departemen lingkungan hidup dan para aktivis lingkungan hidup, tetapi harus menjadi kesadaran kolektif semua pihak, termasuk dunia akademik, bahkan juga mereka yang bergerak di bidang kesusastraan dan kesenian.

Oleh karena itu, isu lingkungan hidup senantiasa terus berkembang dalam wujud karya tulis, baik berupa fiksi maupun nonfiksi. Wacana ekokritik yang memusatkan perhatian tulisan pada lingkungan menjadi sebuah kebutuhan yang penting untuk 
diperhatikan sekaligus digalakkan. Hal ini merupakan salah satu elemen signifikan di era digital untuk membangkitkan kesadaran akan pentingnya lingkungan dalam usaha mewujudkan Sustainable Develeopment Goals (SDGs) untuk mengatasi semakin rusaknya lingkungan yang sebagian besar disebabkan oleh manusia. Selain itu, Presiden Joko Widodo juga menginginkan Indonesia kembali berjaya di balik statusnya sebagai paru-paru dunia yang memiliki keanekaragaman hayati. (nasional.kompas.com/

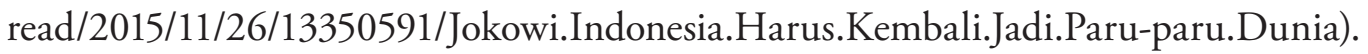

Seperti yang telah disebutkan sebelumnya bahwa salah satu fokus sustainable development goals (SDGs) yang dicanangkan oleh pemerintah Education for Sustainable Development (ESD) dalam bidang sosial dan humaniora yang di antaranya adalah pendidikan akhlak mulia dan pelestarian lingkungan. Dalam hal ini, pondok pesantren dinilai menjadi salah satu model institusi pendidikan di Indonesia yang banyak berkontribusi dalam pembangunan akhlak mulia. Institusi ini mempunyai potensi yang unggul dalam menjadi agen go green dan role model pada lingkungan masyarakatnya.

Salah satu contoh pondok pesantren yang dipandang cukup baik dalam menjadi agen go green dan role model pada lingkungan masyarakatnya adalah Pondok Pesantren Muqimus Sunnah. Namun, hingga saat ini, sentuhan penyadaran lingkungan melalui pendidikan pembelajaran bahasa dan sastra masih sangat jarang dilakukan atau belum pernah sama sekali. Oleh karena itu, Pondok Pesantren Muqimus Sunnah Palembang, tempat pengabdian dilaksanakan, merupakan sasaran yang tepat untuk menumbuhkan kesadaran para remaja dalam kaitannya dengan aksi cinta lingkungan melalui bahasa dan sastra. Melalui dunia literasi, para santri dan guru dapat mengetahui peran bahasa dan sastra dalam meningkatkan kesadaran masyarakat terhadap lingkungan hidup. Para santri dan guru juga bisa mulai menulis fiksi maupun nonfiksi melalui blog, bahkan menerbitkannya dalam bentuk buku antologi karya.

Dari latar belakang di atas, masalah yang kemudian harus diselesaikan adalah cara penyadaran lingkungan hidup melalui workshop penulisan kreatif guru dan siswa di lingkungan pesantren, cara meningkatkan kesadaran tentang lingkungan gerakan penulisan kreatif guru dan siswa, dan cara mengembangkan kepenulisan kreatif yang bersinergi dengan wawasan lingkungan dalam usaha mendukung Sustainable Development Goals (SDGs).

Tujuan dari workshop ini adalah bertambahnya kreativitas generasi muda dalam bidang penulisan kreatif yang berwawasan lingkungan, bertambahnya pengetahuan masyarakat akan pentingnya penulisan kreatif yang berwawasan lingkungan, meningkatnya pengetahuan masyarakat dalam usaha mewujudkan kelestarian lingkungan melalui dunia literasi, dan meningkatnya keterampilan masyarakat dalam menulis yang berwawasan lingkungan sebagai usaha mendukung Sustainable Development Goals (SDGs).

\section{Metode Pelaksanaan}

Workshop pengembangan pembelajaran penulisan kreatif berwawasan lingkungan di Pondok Pesantren Muqimus Sunah Palembang ini diikuti oleh para santri dan ustadz/ ustadzah. Materi dan praktik pelatihan ini berupa proses kreatif menulis karya tulis fiksi dan nonfiksi berwawasan lingkungan. Dalam pelatihan ini juga diberikan permainan 
(game) berwawasan sastra dan lingkungan hidup. Permainan ini bertujuan untuk mengenalkan sastra pada para peserta, sekaligus memperkenalkan karya-karya sastra yang sadar lingkungan.

Oleh karena pelatihan penulisan kreatif berbasis lingkungan hidup merupakan hal baru bagi para santri dan guru, dalam proses latihan para peserta diberikan materi terlebih dahulu tentang pentingnya menjaga lingkungan melalui dunia literasi. Selain itu, peserta langsung dipersilakan untuk praktik, yakni menulis karya fiksi dan nonfiksi. Setelah selesai, para peserta diminta untuk mengumpulkan karya fiksi maupun nonfiksi, baik yang baru dibuat saat itu atau sebelum latihan. Dalam workshop ini, peserta menggunakan beberapa bahan pelatihan berupa modul dan alat peraga agar memudahkan mereka dalam mencerna materi yang diberikan. Alat dan bahan yang digunakan saat pelatihan tersebut antara lain modul yang berkaitan dengan proses kepenulisan kreatif sekaligus mekanisme publikasinya, alat peraga pembelajaran, alat-alat tulis, LCD, sound system, kamera, handycam, dan laptop.

Sebelum pelatihan ini berlangsung, ada beberapa hal yang dipersiapkan, seperti melakukan perizinan ke instansi terkait, yakni Pondok Pesantren Muqimus Sunnah Palembang. Setelah itu, mempersiapan dan menulis modul yang berkaitan dengan proses penulisan kratif yang berwawasan lingkungan, dan dilanjutkan dengan komunikasi dan koordinasi dengan kelompok pengurus pesantren se-Palembang dan MGMP Bahasa Indonesia kota Palembang.

Setelah persiapan selesai, selanjutnya adalah pelaksanaan workshop tersebut. Pertama-tama, melakukan pemetaan kreativitas masyarakat (dalam hal ini guru dan siswa) dalam bidang kepenulisan. Kedua, melakukan workshop penulisan kreatif yang berwawasan lingkungan kepada guru dan siswa. Ketiga, memberikan ceramah mengenai penulisan kreatif yang berwawasan lingkungan untuk mengembangkan isu dan wacana kelestarian alam dalam usaha mendukung Sustainable Developments Goals (SDGs). Keempat, melakukan bimbingan dan pendampingan secara aktif maupun setelah workshop. Selanjutnya, melakukan evaluasi hasil pelaksanaan kegiatan dengan membandingkan pengaruhnya terhadap kesadaran lingkungan yang timbul lewat tulisan yang dihasilkan. Terakhir mengunggah karya dalam blog dan menerbitkan buku hasil karya para santri dan guru.

Di samping itu, tahap penyelesaian pengabdian yang terdiri atas analisis data dan penyusunan draft laporan, diskusi draft laporan dan perbaikan draft laporan, penyusunan laporan akhir, penggandaan dan penyerahan laporan akhir, serta pengunggahan karya, penerbitan dan distribusi buku.

\section{Pengembangan Literasi Sastra di Pondok Pesantren}

Sastra dalam kehidupan dunia pesantren modern sebetulnya bukan hal yang asing. Akan tetapi, kegiatan literasi/bersastra tersebut tidak serta merta merata di semua pondok pesantren, terutama yang berada di luar Pulau Jawa. Selain itu, keterbatasan kesempatan, fasilitas, SDM, dan stimulan kegiatan tulis-menulis menjadikan santri atau siswa banyak yang terasing dari dunia literasi. Sebagai contoh, hingga kini, sebagian besar pondok pesantren tradisional dan semi modern masih melarang para siswanya/ santrinya menggunakan HP dan mengakses internet pada saat mereka belajar di pondok 
pesantren. Komunikasi dengan keluarga biasa dilakukan melalui ustad/ ustadzah dan guru. Demikian pula akses internet ada pembatasan waktu dan di bawah pengawasan guru/pengelola ponpes.

Beberapa pesantren di luar Jawa, misalnya, di daerah Bulukumba, Sulawesi Selatan, ada ponpes yang benar-benar masih melarang/ mengharamkan santrinya untuk mengakses internet. Alasan pengelola ponpes saat itu adalah kekhawatiran terhadap santri yang akan kehilangan fokus belajar agama dan tidak terbendungnya akses pada situs pornografi yang tidak sejalan dengan misi pesantren. Sisi positifnya, para santri menjadi fokus menimba ilmu agama. Namun, sisi negatifnya, mereka jauh tertinggal dengan siswa SMP dan SMA pada umumnya dalam hal informasi, utamanya trend menulis yang sudah berkembang pesat di dunia maya. Pada umumnya mereka mengakses internet pada saat liburan sekolah dan pulang ke rumah keluarganya.

Situasi Ponpes Muqimus Sunnah Palembang berada di tengah-tengah antara pondok pesantren tradisional dan modern. Pengasuh ponpes ini telah berpendidikan S-3, mayoritas guru atau ustad juga perpendidikan S-2. Namun, ponpes ini masih melakukan pembatasan yang ketat terhadap akses internet. Untuk itu, komunikasi melalui media sosial WA dan pengunggahan karya santri dan guru dalam blog guratanpenahijau di internet masih melalui perantara para ustad dan ustadzahnya.

Kegiatan pertama dalam workshop ini adalah pemetaan literasi para santri dan guru. Mayoritas santri berasal dari desa-desa tertinggal dan kabupaten yang jauh dari kota Palembang. Oleh karena itu, banyak yang masih jauh dari kegiatan literasi dan sikap spontanitas berekspresi, terutama ekspresi tulis. Penyampaian pengantar materi penulisan kreatif berwawasan lingkungan merupakan langkah awal yang penting untuk memberikan gambaran kepada para peserta agar memahami pentingnya kritis terhadap isu lingkungan melalui dunia literasi. Melalui ice breaking pada bagian perkenalan, santri diminta menceritakan tentang dirinya dan asal daerah tempat tinggal mereka, beserta kondisi lingkungannya. Beberapa santri juga diminta spontan membaca puisi pengarang besar Indonesia. Sesi ini merupakan sesi edukasi awal tentang penyadaran lingkungan hidup dan kecintaan terhadap keindahan bahasa/sastra.

Dengan adanya workshop ini diharapkan para santri dan ustad/ustadzah semakin mengetahui bahwa dunia literasi mampu memberikan dampak positif terhadap pola pikir masyarakat dalam memperlakukan lingkungan. Selain itu, kegiatan ini juga mengenalkan bahwa dunia tulis-menulis mempunyai dampak intektual, edukasi, kreativitas, dan peluang ekonomi/lapangan kerja alternatif yang cukup menarik. Untuk mencapai tujuan tersebut, pemateri memberikan materi berupa penulisan kreatif fiksi dan nonfiksi. Materi tersebut berguna untuk memberikan wawasan tentang dunia literasi sekaligus memberikan wawasan tentang proses kreatif menulis fiksi dan nonfiksi. Workshop penulisan kreatif berwawasan lingkungan dilakukan untuk memberikan dasar pengetahuan mengenai lingkungan hidup kepada para peserta sekaligus memberikan motivasi akan pentingnya menjaga lingkungan sejak dini. Materi tentang lingkungan hidup dipilih karena semakin banyaknya kerusakan alam yang terjadi. Harapannya, pelatihan ini mampu menambah wawasan dan kesadaran kolektif pada generasi muda untuk mencintai lingkungan. Pengabdi memberikan materi tentang pentingnya menjaga kelestarian lingkungan bagi keberlangsungan makhluk hidup di bumi melalui penumbuhan sikap kritis dan juga menulis. 
Workshop ini dilaksanakan pada 17-19 Mei 2017, bertempat di aula Pondok Pesantren Muqimus Sunnah Palembang. Acara ini dimulai sejak pukul 08.00 sampai dengan 17.00 WIB. Adapun kegiatan ini dimulai dengan penyampaian materi tentang kelangsungan hidup alam dan peran manusia di dalamnya. Disampaikan juga bahwa bumi yang diciptakan Allah hanyalah satu dan harus dipelihara untuk kelangsungan hidup manusia. Kesadaran untuk merawat lingkungan harus dimulai sejak dini melalui perilaku, juga tulisan. Setelah itu, pengabdi juga menyampaikan bahwa mengarang tidaklah sulit sehingga para peserta bisa termotivasi untuk mulai menulis. Menulis juga tidak hanya menjadi sarana hiburan, tetapi juga sarana edukasi.

Setelah penyampaian materi, kegiatan selanjutnya adalah praktik menulis kreatif fiksi dan nonfiksi. Peserta diminta untuk membuat karya fiksi dan nonfiksi berdasarkan pengalaman masing-masing. Untuk menulis fiksi, peserta diberikan stimulasi melihat gambar atau foto yang ditampilkan melalui slide oleh pemateri. Para peserta workshop diminta menuliskan imajinasinya tentang gambar yang ada hubungannya dengan tempat tinggal mereka misalnya jembatan Ampera, sungai, pemendangan alam, sawah, hutan yang gundul, sampah di laut, dan foto-toto features tentang kondisi pendidikan di daerah pedalaman. Hasil tulisan mereka berupa puisi, cerpen, akan dibacakan di depan para guru dan siswa yang lain. Para peserta akan mendapatkan souvenir berupa kaos, mug, dan lain-lain sebagai reward atas jerih payah mereka dalam tiga hari workshop tersebut. Adapun kegiatan pemberian kegiatan menulis nonfiksi, peserta melihat gambar atau foto yang bertema ketimpangan sosial atau kerusakan lingkungan. Hal ini dilakukan sebagai pembelajaran sikap kritis terhadap keadaan lingkungan sehingga para peserta nantinya akan mudah mencerna realitas di lingkungannya masing-masing.

\section{Workshop Penulisan Nonfiksi}

Pengabdi memulai sesi penulisan nonfiksi dengan menayangkan slide terkait proses kreatif menulis nonfiksi. Pengabdi memberikan contoh tulisan artikel tentang lingkungan hidup. Pengabdi menjelaskan jenis-jenis tulisan nonfiksi, seperti tulisan ilmiah populer, artikel, karya tulis ilmiah, dan feature.

Tulisan ilmiah populer biasanya dipublikasikan melalui media massa dan dikonsumsi oleh masyarakat umum. Tulisan ilmiah populer bisa dibaca oleh berbagai kalangan dengan beragaman tingkatan baik status sosial maupun pendidikan. Oleh karena itu, tulisan ilmiah populer berbeda dengan tulisan ilmiah untuk jurnal atau pun seminar. Tulisan ini lebih luwes dan ringan daripada makalah ilmiah/ hasil pengabdian/ skripsi/ tesis. Syaratnya pun lebih sederhana, yakni cukup memenuhi syarat kaidah keilmuan.

Features adalah jenis tulisan yang memadukan antara berita dan opini penulis. Tulisan ini dijelaskan dalam bentuk cerita. Tujuan dari tulisan ini adalah menyampaikan informasi keadaan, kejadian, dan aspek kehidupan secara humanis. Tulisan ini menghidupkan imajinasi pembaca, sekaligus mengajak pembaca masuk dan terlibat dalam sebuah peristiwa yang dituturkan. Untuk membuat karya-karya nonfiksi seperti di atas, ada beberapa langkah yang harus ditempuh. Pertama, tahap persiapan. Pada tahap persiapan ini ada beberapa hal yang perlu diperhatikan, terutama adalah ide. Usahakan untuk membuat ide yang unik, berbeda (out of the box), dan mempunyai daya tarik bagi pembaca. Perlu diingat, karya nonfiksi berbicara persoalan realita atau fenomena yang benar-benar terjadi. Proses selanjutnya adalah mulai menulis. Ada beberapa hal yang 
menjadi poin penting, yakni permasalahan yang diangkat harus jelas, penyelesaian yang ditawarkan harus tepat, dan saran yang diberikan harus membangun. Alur penulisan juga harus jelas. Jangan lupa untuk memperhatikan diksi dan tanda baca.

Setelah tulisan selesai, hal yang harus diperhatikan adalah mengecek kembali seluruh tulisan dari awal hingga akhir dengan teliti. Pastikan tidak ada kesalahan dan salah penulisan. Terakhir, pastikan daftar pustaka sudah tersusun dengan baik, sebab itu adalah salah satu poin utama dalam penulisan sebuah karya nonfiksi.

Selanjutnya, narasumber memberikan materi mengenai penulisan karya ilmiah. Pemateri kemudian menjelaskan bahwa dalam menulis artikel diperlukan beberapa persiapan, misalnya menyiapkan ide tulisan. Trainer juga memperlihatkan contohcontoh artikel dan judul-judul artikel yang unik dan menarik perhatian pembaca. Hal ini penting untuk diberikan guna membekali peserta dalam menulis artikel yang menarik dan berbobot. Judul yang menarik dan muatan yang berbobot akan menarik perhatian, lebih-lebih bila dimasukkan ke media yang memiliki peluang besar untuk diterima dan dimuat.
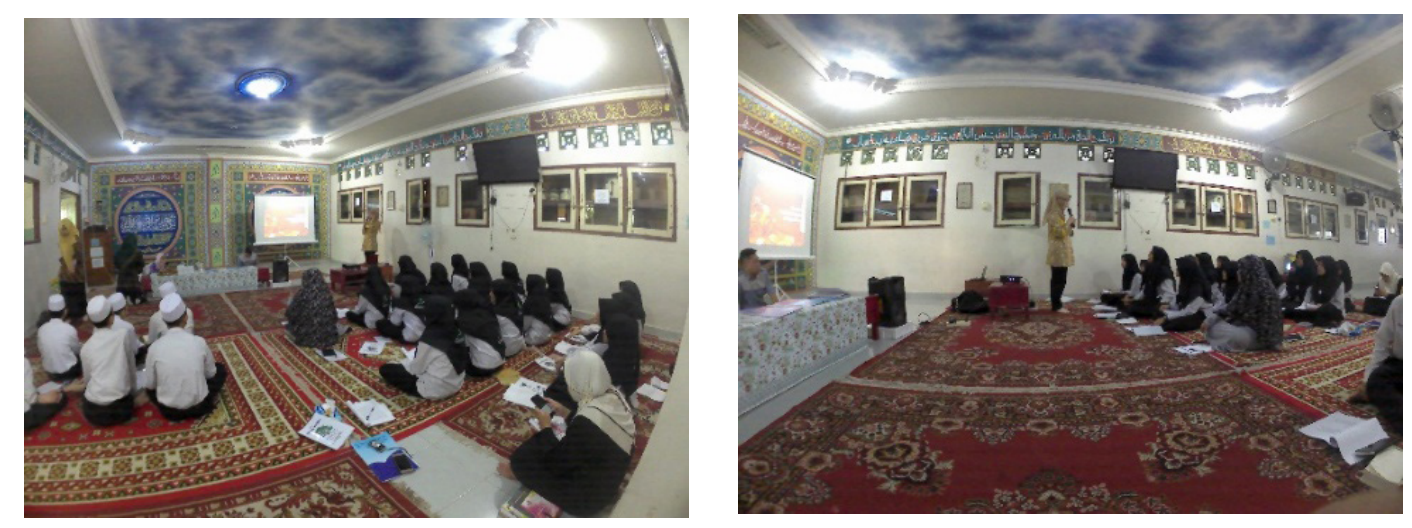

Foto 1 dan 2. penyampaian materi penulisan nonfiksi

\section{Workshop Penulisan Fiksi}

Pada sesi ini, para peserta diberi materi tentang penulisan karya fiksi. Materi ini diperlukan untuk membekali peserta agar memiliki dasar pengetahuan tentang fiksi dan sekaligus sebagai motivasi mereka untuk menulis karya fiksi. Materi penulisan fiksi di antaranya meliputi proses-proses kreatif menulis naskah FTV, menulis cerpen, dan juga menulis skenario film atau drama.

Selain itu, pengabdi juga memberikan materi mengenai sastra hijau. Sastra hijau merupakan fakta kehidupan, pilihan bahasa estetis, plus imajinasi yang datang dari alam. Puisi yang kuat ada pada ide dan pilihan kata yang indah. Pengabdi memberikan beberapa kunci dalam menulis, seperti banyak membaca karya sastra. Jangan takut memulai, jangan takut salah, jelek, atau dikritik. Kirimkan ke surat kabar, media sosial, blog, majalah, panitia lomba, dan penerbit yang cocok. Jika tidak diterima, ulangi menulis dan mengirimkan sampai redaktur merasa bosan. Dan satu hal lagi, jangan kecil hati, minder, dan anti dengan masukan. 

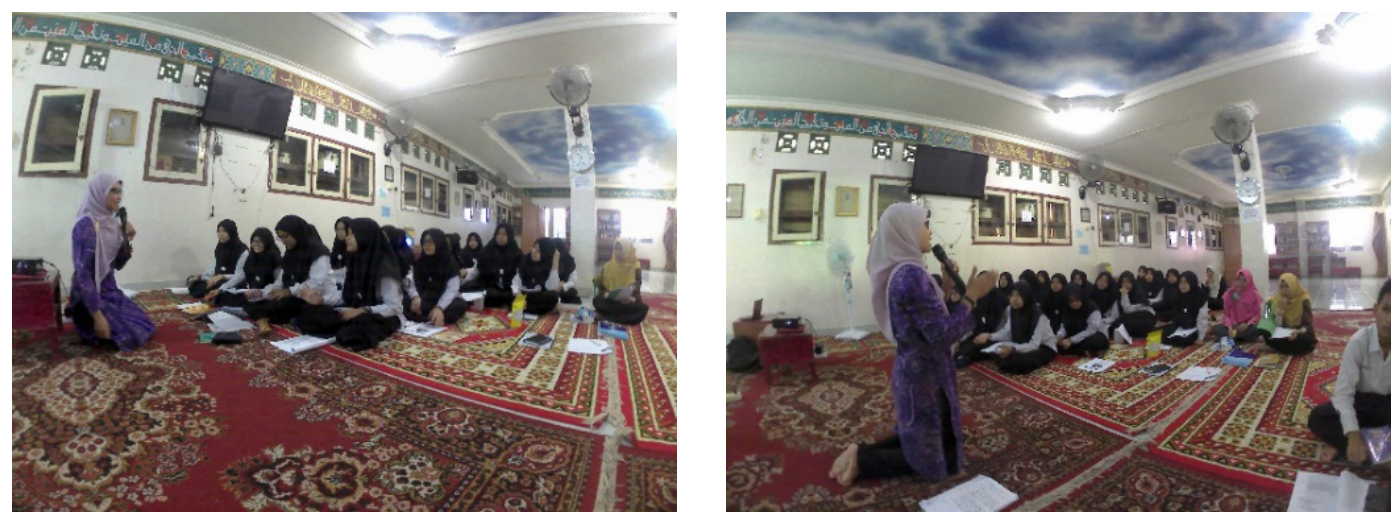

Foto 3 dan 4. Penyampaian materi penulisan kreatif fiksi

\section{Permainan (game) bagi Pembelajaran Sastra dan Lingkungan}

Menurut sebagian orang, permainan adalah aktivitas untuk bersenang-senang, mengisi waktu luang, melepas penat, dan lain-lain. Akan tetapi sekarang, fungsi game tidak lagi hanya sebagai media hiburan dan bersenang-senang, tetapi juga menjadi media pembelajaran. Banyak permainan edukasi yang muncul, yang mana komponen utamanya adalah edukasi/pembelajaran. Hal ini menjadi menarik sebab penyampaian materi oleh pengajar tak lagi bersifat monoton dan konservatif, tetapi bisa lebih asik dan menarik.

Massachussets Insitute of Technology (MIT) berhasil membuktikan bahwa game sangat berguna untuk meningkatkan logika dan pemahaman pemain terhadap suatu masalah. Pengabdian sebelumnya juga menghasilkan keyakinan bahwa game edukasi dapat menunjang proses pendidikan. Sebab, game edukasi mempunyai keunggulan dalam beberapa aspek dibandingkan dengan metode pembelajaran konvensional. Salah satu keunggulan yang signifikan adalah adanya animasi yang dapat meningkatkan daya ingat sehingga anak dapat menyimpan materi pelajaran dalam waktu yang lebih lama dibandingkan dengan metode pengajaran konvensional.

Oleh karena itu, untuk mengasah kepekaan peserta dalam dunia sastra, pengabdi memberikan permainan berupa permainan ular tangga. Papan permainan tersebut berukuran $2 \times 1,5$ meter. Dalam permainan ini, para peserta diminta menjawab pertanyaan, mempraktikkan adegan, bahkan membaca puisi, karena setiap kotak dalam papan ular tangga tersebut memiliki "hukuman". Adapun pertanyaan-pertanyaan yang harus dijawab oleh peserta, yakni seluk-beluk kesastraan, baik tokoh maupun karyanya. Bila lemparan dadu mereka membuatnya masuk dalam kotak baca puisi, mereka diminta untuk membacakan puisi yang sudah disiapkan, yakni puisi-puisi yang menggambarkan lingkungan dan puisi islami.

\section{Luaran Workshop Pembelajaran Penulisan Kreatif}

Dari ketiga kegiatan yang telah dilaksanakan, yakni workshop penulisan fiksi, workshop penulisan nonfiksi, dan game bagi pembelajaran sastra dan lingkungan, dihasilkan satu buah buku antologi Sastra Santri dan blog guratanpenahijau. 

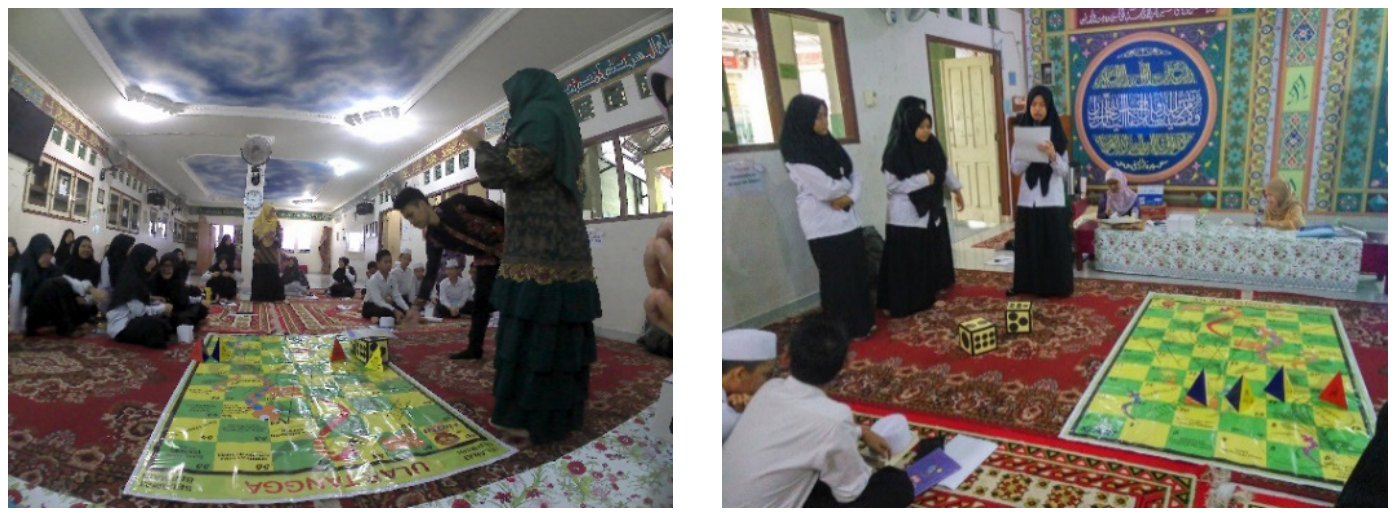

Foto 5 dan 6. Pembelajaran sastra dan lingkungan dengan game
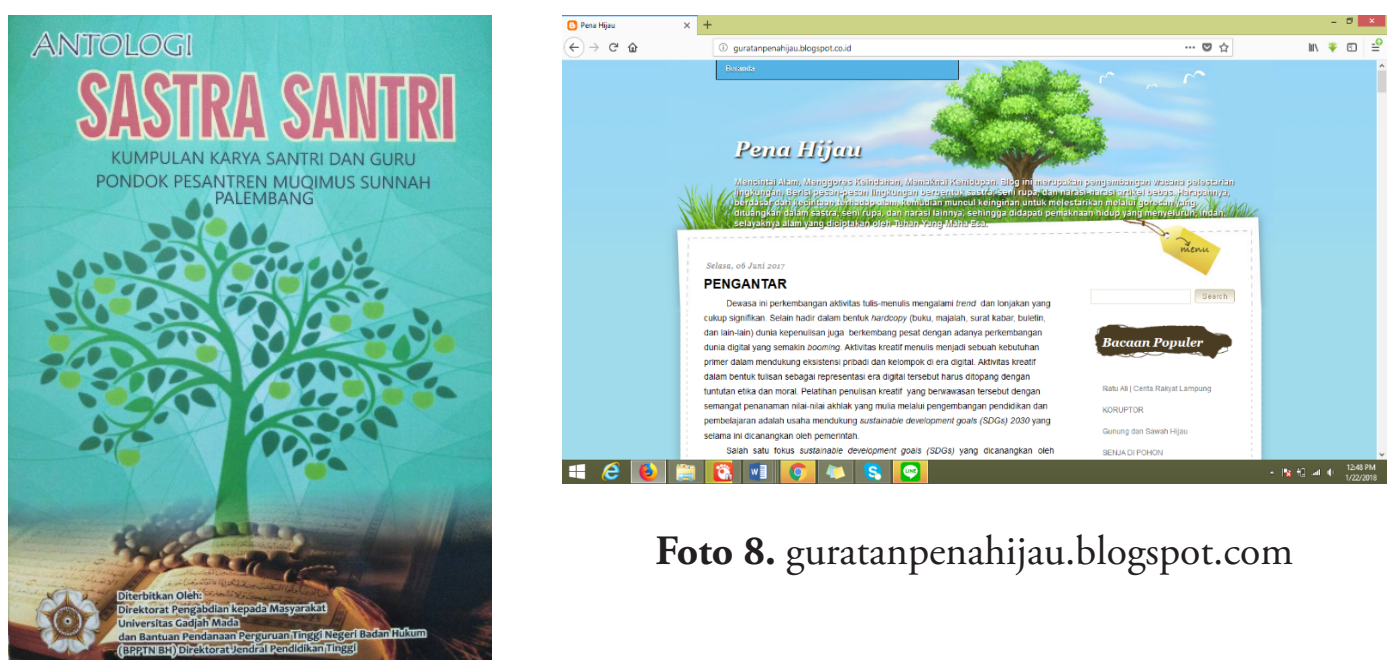

Foto 8. guratanpenahijau.blogspot.com

Foto 7. Buku Antologi

Sastra Santri

\section{Antologi Sastra Santri}

Buku Antologi Sastra Santri merupakan buku kumpulan karya santri dan guru Pondok Pesantren Muqimus Sunnah Palembang. Buku ini terdiri atas 48 puisi, 6 pantun, dan 6 cerita pendek. Buku ini sudah diterbitkan oleh Direktorat Pengabdian kepada Masyarakat Universitas Gadjah Mada dan Bantuan Pendanaan Perguruan Tinggi Negeri Badan Hukum (BPPTN BH) Direktorat Jendral Pendidikan Tinggi.

\section{Guratanpenabijau.blogspot.com}

Blog ini merupakan blog yang dibuat sebagai wadah bagi para santri dan guru Pondok Pesantren Muqimus Sunnah Palembang yang ingin menyalurkan karyanya di dunia maya. Blog ini sudah berisi lebih dari 50 tulisan, baik puisi, pantun, maupun cerita pendek. 


\section{Alat Peraga Sastra}

Alat peraga sastra ini digunakan sebagai alat bantu dalam pembelajaran sastra dan lingkungan yang disampaikan melalui permainan (game). Alat peraga yang digunakan adalah satu set permainan ular tangga.

\section{Modul}

Modul ini berisi materi pembelajaran yang disampaikan, yakni penulisan kreatif fiksi dan nonfiksi.

\section{Kesimpulan dan Saran}

Dari rangkaian kegiatan pengabdian yang dipaparkan di atas dapat disimpulkan bahwa pembelajaran sastra berwawasan lingkungan sangat diperlukan para santri dan ustadz/ ustadzah. Pelatihan menulis, permainan sastra dan lingkungan, serta kritik terhadap kondisi lingkungan sangat diperlukan untuk mengasah kekritisan dan kreativitas para santri maupun guru dalam dunia literasi.

Oleh karena itu, di masa yang akan datang diharapkan pelatihan atau pengabdian semacam ini dapat dilaksanakan di berbagai lembaga-lembaga pendidikan, baik pondok pesantren maupun instansi lainnya di Indonesia.

\section{Daftar Pustaka}

Barry, Peter. (2002). Beginning theory: An introduction to literary and cultural theory. Second Edition. Manchester: Manchester University Press.

Bate, Jonathan. (2000). The song of the earth. London: Picador.

Buell, Lawrence. (1995). The environmental imagination: Thoreau, nature writing, and the formation of American culture. England: Harvard University Press.

Dewojati, Cahyaningrum. (2010). Memperjuangkan harmoni alam dan kearifan lokal dalam Perjuangan Suku Naga karya Rendra. Seminar Antarabangsa Bahasa dan Kesusastraan Melayu yang diselenggarakan Universitas Phuket, di Trang, Thailand.

--------. (2010). Wacana penyadaran lingkungan hidup dalam drama Ozon Karya Arifin C. Noor. Makalah yang disajikan di seminar antarabangsa di USM, Penang, Malaysia.

Estok, Simon C. (2005). 'Shakespeare and ecocriticism: An analysis of 'home' and 'power' in king lear". AUMLA, 103, 15-41.

Garrard, Greg. (2004). Ecocriticism. New York: Routledge.

Glotfelty, Cheryll dan Fromm, Harold. (1996). The ecocriticism reader: Landmarks in literary ecology. Athens and London: University of Georgia.

Meeker, Joseph W. (1972). The comedy of survival: Studies in literary ecology. New York: Scribner's.

Vega, Anik. (2016). Game edukasi sebagai media pembelajaran pendidikan anak usia dini. Jurnal INFORM, I (1), 1-8 